\title{
The Mundane Economics of the Austrian School
}

\author{
Peter G. Klein \\ Division of Applied Social Sciences \\ University of Missouri \\ Columbia, MO 65211 USA \\ 15738827008 \\ 15738823958 (fax) \\ kleinp@missouri.edu
}

This version: 2 October 2008

I thank Per Bylund, Nicolai Foss, David Gordon, Jeff Herbener, Dan Klein, Fabio Rojas, Joseph Salerno, and participants at the 2007 Grove City College Conference in Honor of Ludwig von Mises and the 2007 Austrian Scholars Conference for helpful comments and conversations on this material. The usual caveat applies. 


\section{Introduction}

The Austrian School of economics - the causal-realist, marginalist, subjectivist tradition established by Carl Menger in 1871—has experienced a remarkable renaissance over the last five decades (Vaughn 1994; Rothbard 1995; Oakley 1999; Salerno 1999b, 2002). Austrian economics flourished originally in Vienna during the last three decades of the nineteenth century, and in Europe and North America through the 1920s, then entered a prolonged eclipse in the 1930s and 1940s. Kept alive by important contributions from Hayek (1948), Mises (1949), Lachmann (1956), Rothbard (1962), Kirzner (1973), and others, the Austrian tradition emerged once more as an organized movement in the 1970s, and remains today an important alternative to the “mainstream” tradition of neoclassical economics.

It is not always clear, however, exactly what distinguishes the Austrian School from other traditions, schools of thought, approaches, or movements within economics and its sister disciplines. As a social movement, the Austrian School possesses the formal markers usually taken to demarcate a school of thought, such as its own institutions—specialized journals, conferences, academic societies, and funding agencies - and the patterns of self-citation emphasized by Crane (1972). Here, though, I am concerned not with the sociology of the Austrian School, but with its core theoretical doctrines, propositions, and modes of analysis, particularly as they apply to everyday, pedestrian, ordinary economic problems. These are the basic problems of price theory, capital theory, monetary theory, business-cycle theory, and the theory of interventionism, problems that are central to any approach within economics.

Price theory — the theory of value, exchange, production, and market intervention-was what Mises (1933, p. 214) had in mind when he made the statement, often surprising to contemporary Austrians, that the Austrian, Walrasian, and Jevonian versions of marginalism "differ only in their mode of expressing the same fundamental idea and . . . are divided more by their terminology and by peculiarities of presentation than by the substance of their teachings.” These are not the words of a young, enthusiastic author yet to appreciate the important differences among rival schools of thought; the essay was written in 1932, when Mises was a mature scholar. Hayek, 
likewise, wrote in his 1968 entry for the International Encyclopedia of the Social Sciences that his (fourth) generation of the Austrian School

can hardly any longer be seen as a separate school in the sense of representing particular doctrines. A school has its greatest success when it ceases as such to exist because its leading ideals have become a part of the general dominant teaching. The Vienna school has to a great extent come to enjoy such a success. (Hayek 1968, p. 52)

A few sentences later Hayek singles out "value and price theory" as the key Austrian contribution to modern economics (recognizing, of course, the influence of Marshall, and presumably Hicks, Allen, and Samuelson as well).

These statements hardly can mean that Mises and Hayek failed to recognize the important distinctions among the three marginalist traditions, given their substantial work on the methodology of the Austrian School (Mises 1933, 1962; Hayek 1952). Instead, they indicate that both Mises and Hayek considered value and price theory to be central to the Austrian tradition, an emphasis broadly shared among all theoretical economists. Consider that Mises’s 1932 essay focuses on the differences between theoretical economics and the historicism of the Younger German Historical School. Indeed, Mises's usual doctrinal targets were historicism, institutionalism, and other forms of what he considered to be "anti-economics," not alternative versions of theoretical economics (let alone different strands within the Austrian School). In the fight for theoretical economics, Mises considered the Lausanne and British neoclassical tradition as allies. All three marginalist traditions took value, price, exchange, and production theory to be their central core. ${ }^{1}$

\footnotetext{
${ }^{1}$ Admittedly, Hayek's 1968 assessment of the Austrian School's influence is harder to reconcile with his own insistence (Hayek 1937, 1945, 1946) that neoclassical economists had failed to appreciate the role of knowledge and expectations. Hayek remained ambivalent on this point; in an unfinished draft for the New Palgrave Dictionary, written around 1982 (and reprinted in Hayek, 1992, pp. 53-56), Hayek describes indifference-curve analysis as "the ultimate statement of more than half a century's discussion in the tradition of the Austrian School," adding that "by the third quarter of the twentieth century the Austrian School's approach had become the leading form of microeconomic theory." But he goes on to identify the school's "main achievement" as clarifying the differences between "disciplines that deal with relatively simple phenomena, like mechanics, ... and the sciences of highly complex phenomena.”
} 
Perhaps recognizing the close ties between Austrian value and price theory and that of mainstream economics, recent commentators have looked elsewhere for the distinguishing characteristics of the Austrian School. Klein (2008, p. 361), for example, identifies the Hayekian notion of "spontaneous order" as the main contribution of the Austrian tradition, urging that the label “Austrian,” with its specific historical and geographical connotations, be replaced by "spontaneous order economics” or "Smith-Hayek economics.” Austrian economics, he argues, is part of a broader tradition that includes key figures in the Scottish Enlightenment, French classical liberals of the eighteenth and nineteenth century, and twentieth-century thinkers such as Michael Polanyi. ${ }^{2}$

While I agree with Klein (2008) that the Austrian tradition is part of a larger, liberal movement, I argue here that Austrian economics is nonetheless a distinct kind of economic analysis, and that the essence of the Austrian approach is not subjectivism, the market process (disequilibrium), or spontaneous order, but what I call mundane economics - price theory, capital theory, monetary theory, business-cycle theory, and the theory of interventionism. Call this the "hard core” of Austrian economics. I argue that this hard core is (1) distinct, and not merely a verbal rendition of mid-twentieth-century neoclassical economics; (2) the unique foundation for applied Austrian analysis (political economy, social theory, business administration, and the like); and (3) a living, evolving body of knowledge, rooted in classic contributions of the past but not bound by them. ${ }^{3}$

A different view is found in Vaughn's (1994) influential book on the modern Austrian movement. Vaughn’s characterization of the post-1974 “Austrian revival” has proved controversial (Gordon 1995; Rothbard 1995; Ekelund 1997; Thornton 1999). Her interpretation of the first

\footnotetext{
${ }^{2}$ Koppl (2006) urges Austrian economists to join what he calls the "heterodox mainstream," a body of literature embracing bounded rationality, rule following, institutions, cognition, and evolution, or BRICE. Austrians have "an opportunity to contribute to the heterodox mainstream of today and join, thereby, the emerging new orthodoxy of tomorrow" (Koppl, 2006, pp. 237-38).

${ }^{3}$ My focus here is economic theory, not methodology, so my point is different from Rothbard's (1995) argument that Misesian praxeology, not the alternative Popperian, evolutionary epistemology of the later Hayek or the "radical subjectivism" of Lachmann, is the proper starting point for Austrian economics.
} 
three generations of the Austrian School, by contrast, has received relatively little attention. Vaughn consistently characterizes the price theory of Menger, Böhm-Bawerk, Mises, and Rothbard as backward-looking, inconsistent, and often wrong. Their elaborations of mundane economics, she says, are mainly verbal "neoclassical" economics, because they rely heavily on equilibrium constructs; indeed, Menger's price theory is that of a "half-formed neoclassical economist” (Vaughn 1994, p. 19). Menger’s distinctive Austrian contribution, Vaughn (1994, pp. 18 19) argues, is "his many references to problems of knowledge and ignorance, his discussions of the emergence and function of institutions, the importance of articulating processes of adjustment, and his many references to the progress of mankind.” These issues, which attracted considerable attention during the “Austrian revival” of the 1970s, are discussed in Menger’s 1883 book Untersuchungen über die Methode der Socialwissenschaften und der politischen Oekonomie insbesondere [Investigations into the method of the social sciences with special reference to economics]. They are largely absent from the Principles, however.

Specifically, Vaughn maintains that there is a fundamental contradiction in Menger and Mises's understanding of markets because they simultaneously employ equilibrium theorizing and talk about time, uncertainty, “process,” and in Menger's case, institutions. Mises’s Human Action, for example, combined "some fundamental Mengerian insights with the apparatus of neoclassical price theory to the detriment of both” (Vaughn 1994, p. 70).

I argue here against this characterization of Menger, Mises, and their contemporaries. As explained below, Austrian economists from Menger to Rothbard were fully aware of time, uncertainty, knowledge, expectations, institutions, and market processes. Indeed, their understanding of these issues was sophisticated. They employed equilibrium theorizing, but in a precise and deliberate manner. They understood clearly the distinction between their own understandings of mundane economics and that of their Walrasian and Jevonian colleagues. They devoted their energies to developing and communicating the principles of mundane economics, not because they failed to grasp the importance of knowledge, process, and coordination, but because they regarded these latter issues as subordinate to the main task of economic science, namely the con- 
struction of a more satisfactory theory of value, production, exchange, price, money, capital, and intervention.

\section{Central Themes of Austrian Economics before 1974}

Before 1974, the bulk of Austrian economics dealt with mundane economic subjects. Menger’s Principles (1871), for example, deals entirely with value, price, and exchange (plus a short section on money). Menger intended the Principles as an introduction to a longer, more comprehensive work. The planned sequel was never written, but from Menger's notes, Hayek (1934, p. 69) tells us, "we know that the second part was to treat 'interest, wages, rent, income, credit, and paper money,' a third 'applied' part the theory of production and commerce, while a fourth part was to discuss criticism of the present economic system and proposals for economic reform.” The three volumes of Böhm-Bawerk’s great treatise, Capital and Interest (1884-1912), deal primarily with capital and interest theory but also include the famous sections (in volume II, Positive Theory of Capital) on value and price, introducing the "marginal-pairs" approach to price formation. Wieser's Social Economics (1914) ranges more widely, as did Wieser throughout his career, but still focuses primarily on fundamental questions of value, exchange, production, factor pricing, and international trade. The Anglo-American economists influenced by the Austrians_-Phillip Wicksteed, Frank Fetter, Henry Davenport, and J. B. Clark, for example—also viewed the core of Austrian economics as its theory of value and exchange, not knowledge, expectations, and disequilibrium. ${ }^{4}$

Possibly the most striking example of an Austrian commitment to mundane economics is Rothbard's Man, Economy, and State (1962). Of the 12 chapters in the original edition, all but

\footnotetext{
${ }^{4}$ Interestingly, the third- and fourth-generation Austrians were thoroughly steeped not only in the writings of their Viennese predecessors, but also those of the Anglo-American Mengerian price theorists. Hayek (1963, p. 32) notes that "in the early post-war period the work of the American theorists John Bates Clark, Thomas Nixon Carver, Irving Fisher, Frank Fetter, and Herbert Joseph Davenport was more familiar to us in Vienna than that of any other foreign economists except perhaps the Swedes.” Hayek quotes a letter from Clark to Robert Zuckerkandl in which Clark praises Zuckerkandl's Theory of Price (1889), saying “[n]othing gives me greater pleasure than to render full honor to the eminent thinkers, mainly Austrians, who were earlier in this field than myself, and who have carried their analysis to greater lengths" (Hayek 1939, p. 39) Hayek adds that "at least some of the members of the second or third generation of the Austrian School owed nearly as much to the teaching of J. B. Clark as to their immediate teachers.” Salerno (2006) discusses Clark's influence on Mises.
} 
two focus on the details of value, price, exchange, capital, money, competition, and the like. (Chapter 1 deals with methodological and ontological issues, chapter 12 with the theory of government intervention.) Production theory alone gets five chapters. Even if Power and Market is included, the book contains little about subjective expectations, learning, equilibration, emergent orders, and the like. Perhaps for this reason, Vaughn (1994, p. 96) states that Rothbard's treatise “must have seemed to a typical reader to be more or less familiar economics presented almost exclusively in words with a few controversial definitions, and some strange discontinuous graphs.”

Man, Economy, and State was of course intended as a more elementary and systematic presentation of the contents of Mises's Human Action (1949), which covers a broader range of philosophical, historical, and sociological subjects (Stromberg 2004). Human Action begins, for example, with a lengthy methodological and ontological sections and chapters on "Time” and "Uncertainty.” Still, the bulk of the book - the 16 chapters comprising Parts 3, 4, and 5-deal with the core economic subjects of value, price, and exchange. The same is true, at least partly, of another important postwar contribution to Austrian economics, Lachmann’s Capital and Its Structure (1956). Lachmann's book includes lengthy and insightful discussions of expectations (chapter 2) and “process analysis” (chapter 3), defined as "a causal-genetic method of studying economic change, tracing the effects of decisions made independently of each other by a number of individuals through time, and showing how the incompatibility of these decisions after a time necessitates their revision” (Lachmann 1956, p. 39). ${ }^{5}$ What Lachmann has in mind here is the continual readjustment of the economy's capital structure-he calls it "reshuffling” and "regrouping”—as firms experiment with various combinations of capital goods. Clearly, however, Lachmann has a specific purpose in mind, namely explaining the implications of capital heterogeneity for the theory of production, economic growth, and the business cycle. The book is not focused primarily on meta-theoretic concerns, but on the economic theory of capital itself.

\footnotetext{
${ }^{5}$ Lachmann cites Hicks (1939), Lindahl (1939), and Lundberg (1937) as the main exponents of process analysis, though these theorists are not usually included in the contemporary "market process" tradition.
} 
The main exception to this pattern is Hayek, whose influential essays on knowledge (Hayek 1937, 1945) and competition (Hayek 1948) appeared in the middle of the century. ${ }^{6}$ Of course, Hayek's reputation at this time was based on his technical contributions to monetary and business-cycle theory (see the essays collected in Hayek 2008), and Hayek’s main interests, from his first writings in the late 1920s until his move to Chicago in 1950, remained economic theory, conventionally defined. ${ }^{7}$ More generally, while many members and fellow-travelers of the Austrian School wrote on broad social themes, all regarded technical economics as the heart of the Mengerian project.

By contrast, O’Driscoll and Rizzo’s Economics of Time and Ignorance (1985) contains only a few references to Menger and none to Böhm-Bawerk (outside Roger Garrison’s chapter on capital). After an introduction it contains chapters on "Static versus Dynamic Subjectivism," “Knowledge and Decisions,” “The Dynamic Conception of Time,” and “Uncertainty in Equilibrium.” An application section follows, which features chapters on "Competition and Discovery," “The Political Economy of Competition and Monopoly,” and chapters on capital and money. At least half the book, then, deals with ontological or meta-theoretic issues while the core principles of valuation, price formation, and production theory occupy relatively little space. Or consider the edited volume The Market Process: Essays in Contemporary Austrian Economics (Boettke and Prychitko 1994). Of the book’s five main parts, only one, “Money and Banking,” deals primarily with a conventional economic subject; a section on "Cost and Choice" includes a chapter on utility theory, but even this chapter is primarily ontological, while the remaining sections focus on meta-theoretic issues (with an applied section on political economy).

\footnotetext{
${ }^{6}$ Morgenstern (1935) also dealt with expectations and their role in the formation of economic equilibria.

${ }^{7}$ By the 1950s, Hayek tells us,

I had . . . become somewhat stale as an economist and felt much out of sympathy with the direction in which economics was developing. Though I had still regarded the work I had done during the 1940s on scientific method, the history of ideas, and political theory as temporary excursions into another field, I found it difficult to return to systematic teaching of economic theory and felt it rather as a release that I was not forced to do so by my teaching duties. (1994, p. 126)

Throughout his career at the London School of Economics from 1932 to 1949, Hayek's main teaching obligation had been the required graduate course in economic theory. Of course, he did produce his first important work in classical-liberal political economy, The Road to Serfdom, in 1944.
} 
One might infer that these works take the basic body of causal-realist price theory as given, as so well established that further elaboration is unnecessary, thus preferring to concentrate on advanced applications, methodological foundations, critiques, and the like. However, as attested by the statements from Vaughn (1994) quoted above, Austrians after 1974 by no means accepted the core principles of Austrian price theory as correct, or even as a distinct approach at all, as opposed to a verbal rendition of Walrasian and Marshallian economics. Instead, Austrians after 1974 have tended to regard issues of knowledge, uncertainty, process, and the like as the distinct contribution of the Austrian School.

As noted above, for Vaughn (1994) the most “Austrian” of the classic Austrian texts is Menger's 1883 collection of methodological essays. These essays attempted to defend Menger's theoretical approach against the methods of the (Younger) German Historical School provoking the fierce reaction by Gustav Schmoller and his followers that became a full-blown Methodenstreit. Here Menger presents his theory of "organic" institutions, what Hayek (1973-79, p. 43) termed "spontaneous order.," How is it possible, Menger (1883, p. 146) asks, "that institutions which serve the common welfare and are extremely significant for its development come into being without a common will directed toward establishing them”? Menger's (1892) essay on money provides a detailed example of this process, in which a commonly accepted medium of exchange emerges as a by-product of individual traders' decisions to adopt particular commodities as money. A monetary standard, in this sense, is the "result of human action but not the result of human design” (Hayek 1948, p. 7). ${ }^{9}$ Do these ideas relate to the price theory outlined in Menger's Principles, from which they are largely absent?

First, note that the passage dealing with spontaneous order occupies just two short chapters (30 pages in the 1981 English edition) in a 16-chapter (237-page) book. These chapters are undeniably profound and have exerted an important influence on later Austrians' understanding of

\footnotetext{
${ }^{8}$ See Klein (1997) and Klein and Orsborn (2008) on the differences between Menger's account of institutions and Hayek's understanding of spontaneous order. Klein (1997) argues that Menger's notion of coordination is closer to Schelling's (1978) than Hayek's.

${ }^{9}$ See also Klein and Selgin (2000).
} 
social phenomena (White 1981). However, the bulk of the text deals with Menger's defense of economics as a "theoretical science," with "exact laws," rather than a historical science dealing with historically contingent, "national economies.” Second, Menger’s examples of organic phenomena are not limited to language, religion, law, competition, and money. Indeed, Menger introduces the concept of emergent social processes with a more mundane example: prices.

[We] could point to a long series of phenomena of this kind. We intend, however, to set forth the above idea by an example that is so striking that it excludes any doubt of the meaning of what we plan to present here. We mean the example of the social prices [i.e., market prices] of goods. As is well known, there are in individual cases completely or at least in part the result of positive social factors, e.g., prices under the sway of tax and wage laws, etc. But as a rule these are formed and changed free of any state influence directed toward regulating them, free of any social agreement, as unintended results of social movement. The same thing holds true of interest on capital, ground rents, speculative profit, etc. (1883, p. 146)

In other words, Menger's concept of spontaneous order is simply the process by which voluntary interaction establishes social regularities such as prices, wages, interest rates, rents, and the like. Not only is the market system itself a product of spontaneous order, in this sense, but so are individual market prices.

Menger's presentation here challenges the usual distinction (Davis and North 1971) between the institutional environment (or "rules of the game") and the institutional arrangements (the "play of the game") that emerge in that environment. The new institutional economics (Klein 1998; Williamson 2000) typically treats the former-the legal system, language, norms and custom, and the like—as the results of human action but not human design, while the latter—-firms, contracts, the terms of specific transactions—as the product of deliberate design by particular agents. Menger treats both kinds of institutions as "spontaneous," meaning (generally) undirected by state planners. In other words, for Menger, price theory is not a technical discipline independent of research on spontaneous orders; price theory is spontaneous-order research. Again, in Menger's words:

[M]arket prices, wages, interest rates, etc., have come into existence in exactly the same way as those social institutions which we mentioned in the previous section. 
For they, too, as a rule are not the result of socially teleological causes, but the unintended result of innumerable efforts of economic subjects pursuing individual interests. ... The methods for the exact understanding of the origin of the "organically" create social structures and those for the solution of the main problems of exact economics are by nature identical. (1883, pp. 158-59)

\section{Equilibrium in Mundane Austrian Economics}

Menger's economics, as has been documented elsewhere (Caldwell 1990; Salerno 1999a; Klein 2006), is causal-realist, marginalist, and subjectivist. Despite frequent assertions that Austrian economics is defined as "market process economics" or "disequilibrium economics," the concept of equilibrium features prominently in causal-realist economics (Hülsmann 2000; Gunning 2001; MacKenzie 2008) At least four distinct equilibrium constructs appear in Austrian analysis. Following Mises’s terminology, as amended by Salerno (1994a), we can call them the plain state of rest (PSR), the fully arbitraged state of rest or "Wicksteedian state of rest" (WSR), the final state of rest (FSR), and the evenly rotating economy (ERE). Two of these, the PSR and WSR, describe real-world outcomes, while the FSR and ERE are what Mises called "imaginary constructions," hypothetical scenarios that do not obtain in reality, but are useful in economic reasoning, allowing the theorist to isolate the effects of particular actions or circumstances, holding all else constant.

The PSR obtains every day in the real world, each time a buyer and seller agree on a price and make an exchange, momentarily exhausting the gains from trade. (Menger called these "points of rest”; Böhm-Bawerk, "momentary equilibria.”) A set of potential buyers and sellers interacting in a defined market space can also be described as being in a PSR once the trading period is completed. "When the stock market closes, the brokers have carried out all orders which could be executed at the market price. Only those potential sellers and buyers who consider the market prices too low or too high respectively have not sold or bought” (Mises 1949, p. 245). At this point “[a] state of rest emerges.” The PSR persists as long as market participants' relative valuations of the goods and services being exchanged (including speculative demands) remain constant. 
PSR prices are not necessarily those that would emerge in the "final state of rest" (FSR), a hypothetical situation, never actually achieved, following a sequence of events in which the basic data of the market are frozen but market participants continue to trade, revising their beliefs about other participants' reservation prices and obtaining better information about technological possibilities and consumer demands, until all feasible gains from trade are exhausted. After analyzing the PSR, “[w]e go a step further. We pay attention to factors which are bound to bring about a tendency toward price changes. We try to find out to what goal this tendency must lead before all its driving force is exhausted and a new state of rest emerges” (Mises 1949, p. 246). In the real economy, of course, these underlying factors are constantly changing, and hence the FSR is never achieved. ${ }^{10}$

The FSR is used to trace the effects of changes in tastes, technology, expectations, resource availability, and other exogenous variables on patterns of resource allocation by focusing on a sequence of PSR equilibria in which market participants adjust their behavior until all gains from trade have been exhausted. As Salerno (2006) explains:

FSR analysis also begins from a fully adjusted economy in which profits are currently zero. However in this construction the past and future are relevant to economic planning. Alterations in the economic data are permitted to occur but only one at a time and with a lapse of time between changes sufficiently long to permit a complete adjustment of prices and production in the economy to each change, thus resulting in the emergence of a new zero-profit FSR before another change in the economic data can occur. During the transition to the new FSR, profits and losses appear across the economy spurring entrepreneurs to shuffle and reshuffle resources and capital combinations to take advantage of profit opportunities and avoid losses.

Salerno (2006) notes that Mises modeled his construct after Clark's notion of "dynamic" equilibrium, similar to what is called "comparative statics" in contemporary neoclassical eco-

\footnotetext{
${ }^{10}$ Machlup seems to have the FSR in mind when he writes:
}

To characterize a concrete situation "observed" in reality as one of "equilibrium” is to commit the fallacy of misplaced concreteness. At best, the observer may mean to assert that in his opinion the observed and duly identified situation corresponds to a model in his mind in which a set of selected variables determine a certain outcome, and that he finds no inherent cause of change-that is, that he believes only an outside disturbance, not in evidence at the moment, could produce a change in these variables. This, of course, is a personal judgment, meaningful only if the variables are fully enumerated and the assumptions about their interrelations are clearly stated. (1958, p. 57) 
nomics. Mises “used Clark's construct in formulating a 'step-by step' or 'process' analysis logically demonstrating the sequence of changes which occur throughout the entire interdependent system of markets in the transition to the new FSR"-for example, in tracing the effects of an increase in the money supply on prices and resource allocation. (Modern comparative statics, however, as formalized by Hicks (1939) and Samuelson (1947), abstracts from the element of time.)

It is important to emphasize that the movement from PSR to FSR takes place in analytical time, not calendar time; FSR analysis is a logical exercise, not meant to explain the sequence of events taking place in real markets, for the underlying "data” are in constant flux. This point is not well understood, even among Austrians. For example, Boettke and Prychitko (1994) caution against overreliance on equilibrium theorizing in Austrian economics, even characterizing some of the classic contributions to Austrian economics as "neoclassical Austrianism." 11 "When Austrians refer to proximity to an end state in their treatment of entrepreneurship they may be relying too much on the equilibrium construct” (Boettke and Prychitko 1994, p. 65). However, the causal-realistic price theory of Menger and his followers does not make any assumptions about the "proximity” of PSR or WSR prices to their FSR values in calendar time. Instead, the theorist uses the imaginary construction of the FSR to explain what pattern of activities and ownership would obtain following an exogenous change in preferences, resource availability, or technological knowledge, holding all else constant. The causal-realist theorist does not assume that such adjustments take place in calendar time; indeed, this imaginary process would be impossible in a world in which preferences, stocks, technology, and the like are constantly changing.

Lying between the PSR and the FSR is the WSR, a realistic concept in which trading takes place while preferences remain constant, with market participants revising their beliefs about other participants' reservation prices until all feasible gains from trade are exhausted. Wick-

\footnotetext{
${ }^{11}$ Though specific Austrian writings are not identified, a footnote refers to "relevant sections” of Mises (1949), Rothbard (1962), Kirzner (1973, 1979, 1985) and High (1980, 1982, 1986) as "neoclassical Austrianism.”
} 
steed's (1910, pp. 219-28) fruit market provides the canonical example. ${ }^{12}$ By the end of each market day, a specified period in which preferences, stocks of goods, and the set of traders remains fixed, what Wicksteed calls “the equilibrating price” has been achieved. In this situation, "the marginal position of the commodity in question is identical upon the relative scales of all who have secured a supply, and higher on them all than it is on the scales of any of those who have secured no supply” (Wicksteed 1910, p. 216). The market day is a hypothetical construct, in that it holds only as long as preferences, technical knowledge, stocks of goods available for exchange, and so on are held constant. And yet, the WSR is not a purely imaginary construction, as this process of equilibration takes place in real markets, at least over short periods of calendar time.

Assuming the underlying data are unchanged, [this] approach yields a coherent explanation of how, as information becomes more complete and speculation more accurate, PSRs succeed one another until the intermediate equilibrium situation represented by a fully-arbitraged state of rest (or WSR) is brought into being. (Salerno 1994a, p. 102)

The ERE, used by Mises (1949, pp. 247-51) and Rothbard (1962, pp. 320-28), serves a more limited function. The ERE is an imaginary construction in which preferences, technology, and resource availability are held constant and agents are assumed to repeat the same set of actions each market day. Economic activity takes place-there is production, consumption, saving, and investment-but entrepreneurs can predict the future with certainty. The main function of the ERE is to show that in the absence of uncertainty, factor prices would be bid up to their full discounted marginal revenue products, eliminating entrepreneurial profit and loss. Business owners would still earn interest income if they advance wages to workers and other factor owners before production is completed and sales receipts are realized, and they can earn implicit wages on the labor they supply to the firm, but there can be no profits and losses. Only by using such a con-

\footnotetext{
${ }^{12}$ See also Marget (1938-42, vol. 2), Kirzner (1963, pp. 105-35) and Salerno (1994a, pp. 97-106).
} 
struction, Mises argued, can the theorist decompose real-world business income into interest, the owner's implicit wage, and entrepreneurial profit. ${ }^{13}$

As noted above, the PSR and WSR are intended as realistic phenomena, not hypothetical constructs (like the FSR and ERE). Marshall's “market-day equilibrium” is also intended to explain real-world pricing in markets, something like Wicksteed's WSR, but includes arbitrary assumptions about the marginal utility of money (Walker 1969). ${ }^{14}$ Likewise, Hicks’s “temporary equilibrium”- $\mathrm{a}$ form of Walrasian general equilibrium that incorporates agents' expectations of prices that will obtain in future trading periods - shares elements of the Austrian WSR. However, it is, like Walrasian equilibrium, a deliberately artificial construct, not meant to explain actual market prices but as a modeling step in explaining a concept of intertemporal equilibrium (De Vroey 2002).

Before 1974, then, Austrian economists used the realistic equilibrium constructs of the PSR and WSR, and the imaginary constructions of the FSR and ERE, to explain the basic phenomena of value, production, exchange, and price. Their work was built on Menger's value theory and its underlying concepts of purpose, subjectivism, and uncertainty, and the extensions of the Mengerian approach to deal with price formation under direct exchange (Böhm-Bawerk’s horse market, Wicksteed's fruit market), monetary calculation and indirect exchange, capital theory (the time structure of production and the heterogeneity of capital goods), FSR analysis, the effects of government intervention (business cycle theory, regulation), and other mundane aspects of commercial life.

\section{Knowledge, Expectations, and the Convergence to Equilibrium}

Since the "Austrian revival” of the 1970s the mundane economic subjects described above have commanded relatively little attention. The most popular issues and topics among modern Austrians have included fractional-reserve "free banking," political economy, and the methodo-

\footnotetext{
${ }^{13}$ For additional discussion see Cowen and Fink (1985), Gunning (1989), and MacKenzie (2008).

${ }^{14}$ Just as Mises's (hypothetical) FSR results from a sequence of PSRs, Marshall's “normal equilibrium” is brought about by a series of market-day equilibria (De Vroey 2002).
} 
logical foundations of the Austrian School. During the 1980s, a lengthy debate took place over the existence of "equilibrating tendencies" in the market economy, with Kirzner and Lachmann representing opposite positions (Selgin 1988). Kirzner argued that the existence of profit opportunities under disequilibrium, and the tendency of alert entrepreneurs to discover and exploit these opportunities, was sufficient to establish a general, systematic tendency toward equilibrium. Lachmann, in contrast, maintained that in the face of "radical" uncertainty, including subjective expectations, equilibrating tendencies could not be assumed, absent some explanation for learning. Knowledge, expectations, and the convergence to equilibrium came to occupy center stage in the Austrian research program.

My purpose in this section is not to analyze this debate, but to ask why the problem of convergence to equilibrium received so little attention in early Austrian writings. Neither Menger, Böhm-Bawerk, Wieser, the Anglo-American Austrians, nor Mises devoted much effort to this issue. If the presence or absence of equilibrating tendencies in the entrepreneurial market process is the central problem of price theory, why did the early Austrians fail to recognize it?

First, the modern Austrian literature uses the term equilibrium quite broadly and often inconsistently. O’Driscoll and Rizzo (1985, p. 39), for example, refer to “correct” and "incorrect" prices, identifying the latter with "non-equilibrium" prices, although the equilibrium construct is not defined or discussed in detail until much later in the discussion. Vaughn (1994) refers to “equilibrium models” (p. 2), “equilibrium states” (p. 3), “equilibrium theorizing” (p. 8), “equilibrium constructs" (p. 11), and more—all within the first dozen pages! — but does not provide a formal definition of any equilibrium concept until the discussion of Mises in her fourth chapter (pp. 81-82). There she characterizes Mises’s distinction among three equilibrium constructs (PSR, FSR, and ERE) as "surprisingly unsatisfying” (p. 81), seemingly treating the PSR and FSR 
as equivalent to Marshallian short-run and long-run partial equilibrium, respectively, and the ERE as Mises's own idiosyncratic, and unhelpful, construction. ${ }^{15}$

More generally, the modern Austrian literature on "disequilibrium” is not always careful to define the concept of equilibrium, and virtually never discusses distinctions among the PSR, WSR, FSR, or ERE. O’Driscoll and Rizzo (1985, pp. 80-85) argue that modern Austrians typically have some notion of idea of "plan coordination” in mind. Indeed, all four equilibrium constructs described above involve a form of plan coordination, in the sense that individuals engaged in exchange hold shared beliefs about what is to be exchanged, what price will be paid, and so on. However, as O’Driscoll and Rizzo (1985, p. 80) observe, plan coordination-they call it "Hayekian equilibrium”- -is a very general concept; it "can be partial or general, and can prevail over the various 'runs' of Marshallian time." ${ }^{16}$ Plans can be said to be "coordinated” in the PSR, in the limited sense of coordination just mentioned, without being “coordinated" in any broader sense, as in a longer period of time, a larger set of potential traders or bundles of goods, and so on. As O’Driscoll and Rizzo (1985, pp. 80-81) put it: “Hayekian equilibrium therefore must entail homogenous expectations with respect to the time period within which equilibrium prevails. Outside of that period, however, expectations can, and sometimes must, be divergent.” They go on to conclude that Hayekian equilibrium, in any form, cannot obtain in real exchange. "Hayek and the other Austrians did not realize that equilibrium is not a directly operational construct and that the real world was never in equilibrium” (p. 81). This is clearly false, however, with respect to the PSR (and, to a weaker extent, the WSR), when expressed in "plan coordination” terms.

Rothbard (1962) is somewhat imprecise in distinguishing among equilibrium constructs. His discussion of price determination (pp. 79-186, and passim) focuses mainly on PSR prices,

\footnotetext{
${ }^{15}$ Inexplicably, she accuses Rothbard (1962) of confusing the FSR and ERE, though without providing any specific page reference (Vaughn 1994, p. 82n35). She also says Mises "seemed to confuse his two [sic] distinct notions of equilibrium."

${ }^{16}$ Kirzner (2000) argues for a more nuanced appreciation of Hayek’s commitment to "plan coordination," arguing (against O'Driscoll 1977) that Hayek was ambivalent on the proper notion of coordination in economics. For more on concepts of coordination see Klein (1997) and Klein and Orsborn (2008).
} 
though he occasionally refers to prices that "tend toward" their (WSR) equilibrium values. As described above, every price paid in an actual transaction is a PSR price, so the concept of a market price tending toward its PSR value makes little sense. PSR prices can, of course, be what the Walrasian literature calls "false prices," meaning that they differ from their WSR or FSR values.

In his treatment of expectations Rothbard (1962, pp. 130-37) notes that the formation of PSR prices does not assume perfect knowledge. Indeed, the supply and demand curves underlying PSR analysis incorporate market participants' expectations of future price changes, expectations that may or may not be consistent with those of other market participants. If expectations are incorrect, then shortages and surpluses emerge as market participants trade at PSR pricesRothbard (1962, p. 134) calls them "provisional resting point[s]" - that differ from their values once these price differences have been arbitraged away (a state of affairs presumably like the WSR, though Rothbard is not explicit on this point). As these shortages and surpluses are revealed, market participants will adjust their expectations until the fully arbitraged price, what Rothbard here calls the "genuine equilibrium price," emerges. Rothbard does, then, assume a simple learning process, though he does not spell out the details of this process. However, his assumptions about knowledge and the ability of market participants to learn from their mistakes (“speculative errors”) are minimal. Market participants are assumed to adjust their expectations about the PSR prices that emerge moment-to-moment, in the markets in which these traders are active. In other words, these are very short-run expectations, not long-run expectations (in the Marshallian sense of the long run).

Likewise, the Austrian price theory of Böhm-Bawerk, Wicksteed, Fetter, Mises, and Rothbard treats the movement of prices from PSR to WSR values as a straightforward process. It does not require "perfect knowledge," only that agents are aware of surpluses and shortages (from trading at false prices) and that they adjust their bids accordingly. As noted above, agents' expectations about other agents' preferences are already incorporated into the reservation bids and asks. While these writers were not as explicit about their assumptions concerning knowledge and 
expectations as Mayer (1932), Hayek $(1937,1945)$ and the later Austrians, they were hardly unaware of processes underlying market clearing. Wicksteed, for example, is explicit that forecast errors explain the deviation of PSR prices (the "actual price”) from their WSR equivalents (the “ideal price”):

A market is the machinery by which those on whose scales of preference any commodity is relatively high are brought into communication with those on whose scales it is relatively low, in order that exchanges may take place to mutual satisfaction until equilibrium is established. But this process will always and necessarily occupy time. The persons potentially constituting the market will not all be present at the same time, and therefore the composition of the collective scale (on which, together with the total amount of the commodity in existence, the ideal point of equilibrium depends) must be a matter of estimate and conjecture. The transactions actually conducted at any moment will be determined in relation to the anticipated possibilities of transactions at other moments. Speculation as to these future possibilities will be more or less elaborate and conscious according to the nature of the market and the length of time over which the adjustment will be likely to extend. But speculation is always present when any possessor of the commodity refuses to sell at the moment at a price which he knows he will be prepared to accept ultimately (whether an hour or eleven months hence), if satisfied that he can do no better; or if any purchaser refuses at the moment to give a price to which he knows he will ultimately be willing to rise should the alternative be to go without the commodity; or if any one buys at a price below which he would ultimately sell sooner than keep the stock for his own use. (Wicksteed 1910, p. 236)

These forecast errors are revealed, Wicksteed continues, as traders exchange at non-WSR prices in real time:

If no one at first has a correct conception of the facts, a series of tentative estimates, and the observation of the transactions that take place under their influence, may gradually reveal them; and if we could eliminate all error from speculative estimates and could reduce derivative preferences to exact correspondence with the primary preferences which they represent, and on which they are based, the actual price would always correspond with the ideal price. (pp. 236-37)

Salerno (1994a, p. 105) notes that Mises, in The Theory of Money and Credit, invokes arbitrage in his account of purchasing power parity (Mises 1912, pp. 195-203). "The money price of any commodity in any place, under the assumption of completely unrestricted exchange and disregarding the differences arising from the time taken in transit, must be the same as the price at 
any other place, augmented or diminished by the money cost of transport” (pp. 196-97). Hence, Mises argues,

the purchasing power of money shows a tendency to come to the same level throughout the world, and that the alleged differences in it are almost entirely explicable by differences in the quality of the commodities offered and demanded, so that there is only a small and almost negligible remainder left over, that is due to differences in the quality of the offered and demanded money.

The existence of the tendency itself is hardly questioned. (p. 198; emphasis in original)

Mises continues:

Nobody would wish to dispute the fact that costs of production differ greatly from one another in different localities. But it must be denied that this exercises an influence on the price of commodities and on the purchasing power of money. The contrary follows too clearly from the principles of the theory of prices, and is too clearly demonstrated day by day in the market, to need any special proof in addition. The consumer who seeks the cheapest supply and the producer who seeks the most paying sale concur in the endeavor to liberate prices from the limitations of the local market. (pp. 199-200)

Note that Mises treats the "tendency" of the purchasing power of money to equalize across and within markets, less transportation costs, as “clearly demonstrated day by day in the market," i.e., as an empirical fact not requiring special explanation.

Here it is worth emphasizing a methodological point. For modern, neoclassical economists, the instrumentalist approach (Friedman 1953) renders moot many such questions about the mechanics underlying market-clearing processes. The goal of economic theory, in this approach, is not to explain actual prices, but to explain hypothetical prices (for example, full-information prices, Nash equilibrium prices, perfectly competitive prices, and the like). It is unlikely that Menger and his followers, steeped in the causal-realist tradition, would simply assume that “equilibrium” obtains — after all, they were seeking to explain real prices, not hypothetical ones. They saw the processes of buyers and sellers making bids and asks, of revising their offers in 
light of new information, and so on as real-world phenomena, not instrumental constructs like the Walrasian tâtonnement. ${ }^{17}$

Lachmann, while expressing reservations about the logical consistency of market-level equilibrium constructs such as the WSR, nonetheless recognized that Menger's points of rest, BöhmBawerk’s momentary equilibrium, and Mises's plain state of rest represent real phenomena

The Austrians were concerned, in the first place, with the individual in household and business. There is no doubt that here equilibrium has a clear meaning and real significance. Men really aim at bringing their various actions into consistency. Here a tendency towards equilibrium is not only a necessary concept of praxeology, but also a fact of experience. It is part of the logic inherent in human action. Interindividual equilibrium, such as that on a simple market, like Böhm-Bawerk's horse market, already raises problems but still makes sense. "Equilibrium of an industry" à la Marshall is already more precarious. "Equilibrium of the economic system as a whole," as Walras and Pareto conceived of it, is certainly open to Mises's [anti-equilibrium] strictures. (Lachmann 1977, p. 189)

In other words, the deliberately unrealistic character of the equilibrium constructs that dominate neoclassical economics - and, by implication, Austrian concepts like the FSR and ERE—does not render the equilibrium concept itself unrealistic.

Clearly, the Mengerian price theorists did not assume that real prices were FSR or ERE prices. They allowed for subjective, heterogeneous beliefs about changes in demand, resource availability, knowledge, and the like. And Mises (1949, p. 247) is clear that the movement from the PSR to the FSR takes place in analytical time, not calendar time. "Between the appearance of a new datum and the perfect adjustment of the market to it some time must pass. (And, of course,

\footnotetext{
${ }^{17}$ De Vroey argues that Marshall, too, regarded his market-day equilibrium construct as both realistic and practical, i.e., not requiring an underlying adjustment process:
}

Two adjustment processes are present [in Marshall]: the adjustment toward market-day equilibrium and the adjustment toward normal equilibrium. In my view . . . the former should be interpreted as proceeding instantaneously, whereas the latter (to be called intertemporal adjustment) arises across several trading rounds....

The stationary equilibrium concept of equilibrium is in accord with the common-sense understanding of equilibrium-i.e., it is a point of rest. It is implied that this point does not need to be effectively reached; it suffices that reacting forces are triggered whenever it is not reached. Equilibrium is thus viewed as an attractor. ... Note also that in this line of thought, assessing the existence of equilibrium or disequilibrium amounts to making a statement about reality. (2002, pp. 406-07) 
while this period of time elapses, other new data appear.)" In other words, the real economy does not converge on a FSR because as the market is adjusting to one change in the data, another takes place, the combined effects of which cannot be known ex ante. Hence the accuracy of realworld expectations is not central to this approach. These theorists make no assumptions about the tendency or PSR and WSR prices to converge toward some "final" values.

What about "radical uncertainty"? One can perhaps imagine a market in which PSR prices do not "converge" toward WSR prices because of endogenous, subjective expectations. However, as discussed above, it is not clear that such a case has much practical significance, because the movement from the PSR to the WSR requires only modest assumptions about knowledge (namely, the ability of market participants to learn from their mistakes). Even in the simplest, pureexchange economy, Mengerian price theory allows traders to have subjective expectations relevant to that particular market (i.e., beliefs about other traders' preferences), expectations that are incorporated into the PSR supply and demand curves.

Vaughn argues that much stronger assumptions about knowledge and expectations are necessary for economic analysis, even (presumably) for Mengerian price theory.

If all action is speculation, if people are constantly reevaluating their preferences, if entrepreneurs make losses as well as profits, can we be so certain that markets are fundamentally orderly? Perhaps our world is one in which individual rationality leads to overall waste and error. ... Even more to the point, in a world of constant change, how can people's plans come to be realized? Why are speculators likely to be more right about entrepreneurial prospects than the entrepreneurs themselves? And how is successful rational action distinguishable from pure luck? What are the regularities in economic life that can be counted on to lend stability and predictability to an otherwise bewildering world? (Vaughn 1994, p. 91)

Most likely Menger, Böhm-Bawerk, Wieser, Mises, and their Viennese contemporaries would have been baffled by the last statement in the quotation above. The science of economics, in Menger's formulation, is about the explanation of regularities - the "exact laws" of reality described in the Investigations. As Menger wrote to Walras in 1884:

It is rather necessary that we go back to the most simple elements of the mostly very complex phenomena that are here in question - that we thus determine in an 
analytical manner the ultimate factors that constitute the phenomena, the prices, and that we then accord to these elements the importance that corresponds to their nature, and that, in keeping with this importance, we try to establish the laws according to which the complex phenomena of human interaction result from simple phenomena. (quoted in Hülsmann 2007, p. 106)

As Bastiat (1850) observed, Paris gets fed. The task of economics is to explain why.

The early Austrians' emphasis on order helps us understand Mises’s and Hayek's statements, quoted at the beginning of the paper, about the close relationship between Austrian and neoclassical economics. Menger, Walras, and Jevons all sought to explain the regularities of economic life. The historicists, by contrast, saw the economy as a chaotic flood that defied rational explanation. Indeed, some contemporary interpretations of Austrian economics seem to place it closer to the German Historical School than the Austrian School. Vaughn, for example, writes of Mises:

[W]hat about sources of discoordination and disorder in [free, unhampered] markets? Mises really had very little to say about such problems, and in fact one concludes that he thought disorder was a relatively minor problem.... [T]he only obvious sources of instability or disorder in his system were the consequences of bad banking institutions and destabilizing intervention on the part of government. Trade cycles were brought about by misguided credit policies. Unemployment was a consequence of minimum wage rates. Inflation was an increase in the quantity of money brought about by government policy. Externalities were the consequence of imperfectly specified property rights. He never considered possible sources of disorder internal to the market; disorder was an exogenous phenomenon brought about by government regulation....

In this attitude ... Mises is really not very different from many neoclassical economic theorists (although perhaps more consistent and more outspoken than others who shared his basic evaluation of the market). (Vaughn 1994, p. 90)

I think Vaughn is correct that Mises thought "disorder," in the sense she describes above, was a "relatively minor problem." For Mises, economic theory is the analysis of coordinationnot the idea of "plan coordination” often associated with Hayek, or what O’Driscoll and Rizzo (1985) call "pattern coordination," but what Mises, following W. H. Hutt, described as "price coordination” (Salerno 1991). This coordination, as noted below does not require any assumptions about the tendency of PSR or WSR prices to converge to FSR values. Full coordination of 
plans occurs only in the ERE, a hypothetical state of affairs that does not (indeed, could not) occur in the real economy. For Mises, following Clark (1889), the FSR is an analytical device used to isolate the effects of specific changes in preferences, beliefs, resource availability, productive technology, and the like on the allocation of resources. ${ }^{18}$

What does Mises mean by coordination, outside an imaginary world of perfect knowledge, consistent expectations, "rational" behavior, and the other assumptions of the First and Second Welfare Theorems of neoclassical economics? How, in other words, can Mises justify the efficiency of resource allocation under capitalism without making strong assumptions about the closeness of real-world prices to some idealized, or "correct," prices?

Central to the neoclassical notion of efficiency is the idea that only FSR prices count for assessing the welfare properties of the market. ${ }^{19}$ A primary objective of Kirzner's account of the entrepreneurial market process is to show that the movement from PSR prices to their Marshallian/Walrasian FSR equivalents is not automatic and instantaneous, but the result of entrepreneurial behavior. In Kirzner's framework, the market does possess equilibrating tendencies, but these tendencies are not exogenous, but result from the actions of entrepreneurs alert to the profit opportunities created by temporary trading at false, i.e., non-FSR, prices. For Kirzner, PSR prices themselves are not particularly important; what matters is whether they tend to converge toward their FSR values. Kirzner's concept of alertness can thus be seen as an addendum to the neoclassical understanding of market equilibrium. Kirzner’s approach, as Boettke (Boettke and Prychitka 1994, p. 3) describes it, "provided the disequilibrium foundations of equilibrium economics that were required to complete the neoclassical project of explicating the operating principles of the price system.” Kirzner's objective, in this sense, is to justify the use of FSR, or nearFSR, prices in welfare analysis. If the market possesses equilibrating tendencies, then the welfare theorems of neoclassical economics are reasonable criteria for assessing market performance,

\footnotetext{
${ }^{18}$ Note that Clark (1907, p. 96) describes simple FSR analysis or comparative statics—e.g., if the supply increases, the price will fall, ceteris paribus - as obvious, as what he calls a "commercial fact."

${ }^{19}$ And these FSR prices are only "efficient" in perfectly competitive markets; any degree of asymmetric information renders economic outcomes inefficient (Grossman and Stiglitz 1980).
} 
and the main talk of welfare economics should be the analysis of these tendencies and of market interventions that inhibit the process of equilibration (Kirzner 1988). ${ }^{20}$

Salerno (1991, 1999b) offers a different interpretation of Mises, arguing that Mengerian price theory is primarily a theory of PSR prices, not FSR prices. In this view, the existence or nonexistence of equilibrating tendencies in the unhampered market — the issue that divided "Kirznerians” and "Lachmannians," and dominated much of the Austrian discussion in the 1980s-is relatively unimportant. For Mises, the critical “market process” is not the convergence to equilibrium, but the selection mechanism in which unsuccessful entrepreneurs- those who systematically overbid for factors, relative to eventual consumer demands-are eliminated from the market (Mises 1951). In this context, the recent debate over “de-homogenizing” Mises and Hayek (Rothbard 1991; Salerno 1993, 1994b, 1996; Yeager 1994, 1995, 1997; Herbener 1996; Hoppe 1996; Stalebrink 2004) deals not simply with the socialist calculation debate or second-order distinctions between “calculation” and "knowledge,” but with a fundamentally new interpretation of Austrian price theory, a causal-realist approach to the market that differs in important ways from the Marshallian/Walrasian analysis that fills the contemporary textbooks. Austrian economics, in this view, is not simply neoclassical microeconomics - what Caldwell (2004, pp. 328-88) calls "basic economic reasoning”- plus the Mises-Hayek theory of the business cycle plus knowledge, process, plan coordination, and spontaneous order, but a fundamentally different kind of microeconomics. $^{21}$

${ }^{20}$ Adds Boettke (2005):

Why is all this important? Well as Franklin Fischer pointed out in his very important book The Disequilibrium Foundations of Equilibrium Economics (1983) that unless we have good reasons to believe in the systemic tendency toward equilibrium we have no justification at all in upholding the welfare properties of equilibrium economics. In other words, without the sort of explanation that Kirzner provides the entire enterprise of neoclassical equilibrium is little more than a leap of faith.

If one rejects the neoclassical equilibrium concept as a welfare benchmark, though, this justification is unnecessary.

${ }^{21}$ Caldwell (2004, pp. 333) argues that Austrians accept "the simple (although unrealistic) models used for basic economic reasoning," such as supply-and-demand analysis, at least for market-level predictions. But Menger's analysis, while abstract, is not unrealistic in the sense of Walras's or Marshall's models of market exchange. In Long's (2006) terminology, Austrians reject "precisive abstraction," in which false assumptions are deliberately included to simplify the analysis, while embracing "non-precisive abstraction," in which certain characteristics of the situation 
In a recent response to Salerno, Kirzner (1999) takes a characteristically subtle position on the relationship between PSR and FSR prices. He argues the PSR is an "equilibrium” only in a trivial sense and that PSR prices are not meaningful for assessing the welfare properties of markets. He also recognizes that PSR analysis was important to Mises. To solve this seeming contradiction, he says that Mises used the PSR only to defend the concept of consumer sovereignty, not for analysis of the market process. However, if PSR prices are sufficient to assure that production is satisfying consumer wants, it is unclear why FSR prices are important, and why one would care about the alleged tendency of PSR prices to reach them.

\section{A New Way forward for Austrian Economics: Developing the Mundane Paradigm}

The main argument of this paper is that Austrian economics is primarily mundane economics - the theory and applications of value, production, exchange, price, capital, money, the firm, regulation, comparative institutions, and other "mainstream" topics. What makes Austrian economics unique is its causal-realist approach to these issues, not its attention to adjustment processes, the formation of knowledge and expectations, spontaneous order, plan or pattern coordination, radical subjectivism, and other manifestations of “disequilibrium” economics. Such issues are interesting and potentially important, but are ultimately subordinate to the main task of economic analysis, the development, extension, application, and refinement of the mundane Austrian tradition established by Menger. Naturally, this means that students of Austrian economics must invest significant time in mastering the existing literature before engaging in their own creative restatement and revision.

To give only one example, Austrian economics is attracting increasing attention among applied researchers in business administration, in fields such as strategic management, organizational economics, and the theory of the firm (Jacobson 1992; Foss and Klein 2002; Roberts and Eisenhardt 2003; Yu 2003; Mathews 2006; Foss, Foss, Klein, and Klein 2007; Chiles, Bluedorn, and Gupta 2007). Often the value-added of Austrian economics in these fields is seen as its em-

are simply not specified. In other words, the "basic economic reasoning” of the Austrians is different from the basic economic reasoning of neoclassical economics. 
phasis on disequilibrium, which seems to fit the profit-seeking approach of strategic management better than do neoclassical partial- and general-equilibrium models. Here a more sophisticated and nuanced understanding of equilibrium would be helpful, however. Organizational structures that are implemented, contracts that are signed and executed, and other business arrangements that take place in real markets are equilibrium phenomena, in the PSR sense of equilibrium. They should be explainable using the same causal-realistic mechanism used by the Austrians to explain real prices and quantities. FSR analysis, as practiced by Mises, should also apply here: how, for instance, does the profit-and-loss mechanism provide incentives for agents to restructure PSR arrangements so that they move toward their FSR equivalents? How do changes in regulation or other aspects of public policy, or exogenous changes in the competitive or technological environments, replace one PSR with another?

Unfortunately, despite the pleas of modern Austrians for more analysis of "process," very little progress has been made in this area within the Austrian literature. Indeed, the bulk of the work during the last few decades in evolutionary economics, dynamic programming, evolutionary game theory, Bayesian learning models, agent-based simulations, complexity theory, and the like is fundamentally a-causal and nonrealistic, an extension of the mathematical economics of the late nineteenth and early twentieth centuries. O’Driscoll and Rizzo (1985, pp. 65-66) cite some examples of these literatures, implying that they are "Hayekian" in spirit; however, despite sharing certain keywords with Austrian economics, it is unclear that these research programs have been influenced in any way by the core contributions or approach of the Austrian School.

Of course, the argument here is not knowledge, expectations, and process are unimportant, or that they should be ignored by Austrians (or by any social scientists), but that they are secondary, and valuable only to the extent they help construct a more satisfactory theory of markets and prices. Austrian economics emerged as a causal, realistic alternative to the historicism of its day, and remains today an alternative both to mechanistic neoclassical economics and to the noneconomics of old-style institutionalism. Without a commitment to preserving and extending the hard core of Austrian price theory, the distinct place of the Austrian School will be lost. 


\section{References}

\section{References}

Bastiat, Frédéric. 1850. Economic Harmonies. Trans. W. Hayden Boyers. Irvington-on-Hudson, N.Y.: Foundation for Economic Education, 1996.

Boettke, Peter J.. 2005. “Kirzner.” The Austrian Economists, September 10. Accessed September 16, 2008.

Boettke, Peter J., and David L. Prychitko, eds. 1994. The Market Process: Essays in Contemporary Austrian Economics. Aldershot: Edward Elgar.

Böhm-Bawerk, Eugen von. 1884-1912. Capital and Interest. South Holland, Ill.: Libertarian Press, 1959.

Caldwell, Bruce J., ed. 1990. Carl Menger and His Legacy in Economics: Annual Supplement to Volume 22: History of Political Economy. Durham, N.C.: Duke University Press.

—. 2004. Hayek's Challenge: An Intellectual Biography of F. A. Hayek. Chicago: University of Chicago Press.

Chiles, Todd H., Allen C. Bluedorn, and Vishal K. Gupta. 2007. "Beyond Creative Destruction and Entrepreneurial Discovery: A Radical Austrian Approach to Entrepreneurship.” Organization Studies 28(4): 467-93.

Clark, John Bates. 1899. The Distribution of Wealth: A Theory of Wages Interest and Profits. New York: Macmillan.

Clark, John Bates. 1907. Essentials of Economic Theory. New York: Macmillan.

Cowen, Tyler, and Richard Fink. 1985. "Inconsistent Equilibrium Constructs: The Evenly Rotating Economy of Mises and Rothbard.” American Economic Review 75(4): 866-69.

Crane, Diana. 1972. Invisible Colleges: Diffusion of Knowledge in Scientific Communities. Chicago: University of Chicago Press.

Davis, Lance E., and Douglass C. North. 1971. Institutional Change and American Economic Growth. Cambridge: Cambridge University Press.

De Vroey, Michel. 2002. Equilibrium and Disequilibrium in Walrasian and Neo-Walrasian Economics.” Journal of the History of Economic Thought 24(4): 405-22.

Ekelund, Robert B. 1997. Review of Vaughn, Austrian Economics in America. Review of Austrian Economics 10(2): 133-38.

Foss, Kirsten, Nicolai J. Foss, Peter G. Klein, and Sandra K. Klein. 2007. “The Entrepreneurial Organization of Heterogeneous Capital.” Journal of Management Studies 44(7): 1165-86. 
Foss, Nicolai J., and Peter G. Klein, eds. 2002. Entrepreneurship and the Firm: Austrian Perspectives on Economic Organization. Aldershot, U.K.: Edward Elgar.

Friedman, Milton. 1953. “The Methodology of Positive Economics.” In Friedman, Essays in Positive Economics. Chicago: University of Chicago Press. Pp. 3-43.

Gordon, David. 1995. Review of Vaughn, Austrian Economics in America. Reviewed in Mises Review 1(3): 19-25.

Grossman, Sanford J., and Joseph E. Stiglitz. 1980. "On the Impossibility of Informationally Efficient Markets.” American Economic Review 70(3): 393-408.

Gunning, J. Patrick. 1989. “Mises on the Evenly Rotating Economy.” Review of Austrian Economics 3(1): 123-35.

—_. 2001. “The Praxeological Concept of Equilibrium.” Working paper.

Hayek, F. A. 1934. “Carl Menger (1940-1921).” In Hayek 1992. Pp. 61-107.

—. 1937. “Economics and Knowledge.” In Hayek 1948. Pp. 33-56.

—. 1939. Review of John Bates Clark: A Memorial. In Hayek 1992. Pp. 38-39.

—_. 1945. “The Use of Knowledge in Society.” In Hayek 1948. Pp. 77-91.

—. 1946. “The Meaning of Competition.” In Hayek 1948. Pp. 92-106.

—. 1948. Individualism and Economic Order. Chicago: University of Chicago Press.

- 1952. The Counter-Revolution of Science: Studies on the Abuse of Reason. Glencoe, Ill.: The Free Press

—. 1963. “The Economics of the 1920s as Seen From Vienna.” In Hayek 1992. Pp. 19-41.

—. 1968. “The Austrian School of Economics.” In Hayek 1992. Pp. 42-60.

—.1973-79. Law, Legislation, and Liberty. 3 vols. Chicago: University of Chicago Press.

- 1992. The Fortunes of Liberalism: Essays on Austrian Economics and the Ideal of Freedom. Vol. 4 of The Collected Works of F. A. Hayek. Ed. Peter G. Klein. Chicago: University of Chicago Press.

—. 1994. Hayek on Hayek: An Autobiographical Dialogue. Eds. Stephen Kresge and Leif Wenar. Chicago: University of Chicago Press.

- 2005. Prices and Production and Other Works: F. A. Hayek on Money, the Business Cycle, and the Gold Standard. Ed. Joseph T. Salerno. Auburn, Ala.: Ludwig von Mises Institute. 
Herbener, Jeffrey M. 1996. "Calculation and the Question of Arithmetic." Review of Austrian Economics 9(1): 151-62.

Hicks, John R. 1939. Value and Capital: An Inquiry into Some Fundamental Principles of Economic Theory. Oxford: Clarendon Press, 1946.

High, Jack C. 1980. Maximizing, Action, and Market Adjustment: An Inquiry into the Theory of Economic Disequilibrium. PhD Dissertation, Department of Economics, University of California, Los Angeles.

—. 1982. "Alertness and Judgment: Comment on Kirzner." In Method, Process, and Austrian Economics: Essays in Honor of Ludwig von Mises. Ed. Israel Kirzner. Lexington, Mass.: D.C. Heath.

—. 1986. "Equilibrium and Disequilibrium in the Market Process.” In Subjectivism, Intelligibility, and Economic Understanding. Ed. Israel M. Kirzner. New York: New York University Press.

Hoppe, Hans-Hermann. 1996. “Socialism: A Property or Knowledge Problem?” Review of Austrian Economics 9(1): 143-49.

Hülsmann, Jörg Guido. 2000. “A Realist Approach to Equilibrium Analysis.” Quarterly Journal of Austrian Economics 3(4): 3-51.

—_ 2007. Mises: The Last Knight of Liberalism. Auburn, Ala.: Ludwig von Mises Institute.

Jacobson, Robert. 1992. “The ‘Austrian’ School of Strategy.” Academy of Management Review 17: 782-807.

Kirzner, Israel M. 1963. Market Theory and the Price System. Princetonn N.J.: D. Van Nostrand.

—_. 1973. Competition and Entrepreneurship. Chicago: University of Chicago Press.

—. 1979. Perception, Opportunity and Profit: Studies in the Theory of Entrepreneurship. Chicago: University of Chicago Press.

— 1985. Discovery and the Capitalist Process. Chicago: University of Chicago Press.

— . 1988. "Welfare Economics: A Modern Austrian Perspective.” In Man, Economy and Liberty: Essays in Honor of Murray N. Rothbard. Eds. Walter Block and Llewellyn H. Rockwell, Jr. Auburn, Ala.: Ludwig von Mises Institute.

—. 1999. "Mises and His Understanding of the Capitalist System." Cato Journal 19(2): 21532.

— 2000. "Hedgehog or Fox? Hayek and the Idea of Plan-Coordination.” In Kirzner, The Driving Force of the Market Economy: Essays in Austrian Economics. London: Routledge. Pp. 180-202. 
Klein, Daniel B. 1997. "Convention, Social Order, and the Two Coordinations.” Constitutional Political Economy 8: 319-35.

—. 2008. “Toward a Public and Professional Identity for Our Economics.” Econ Journal Watch 5(3): 358-72.

Klein, Daniel B., and Aaron Orsborn. 2008. “Concatenate Coordination and Mutual Coordination.” Working Paper 116, Ratio Institute.

Klein, Peter G. 1998. “New Institutional Economics.” In Encyclopedia of Law and Economics. Eds. Boudewijn Bouckeart and Gerrit De Geest. Cheltenham, U.K.: Edward Elgar, 2000. Pp. 456-89.

—. 2006. "Foreword” to Carl Menger, Principles of Economics. Reprint. Auburn, Ala.: Ludwig von Mises Institute, 2006. Pp. 7-10.

Klein, Peter G., and George A. Selgin. 2000. "Menger’s Theory of Money: Some Experimental Evidence.” In What Is Money? Ed. John Smithin. London: Routledge. Pp. 217-34.

Koppl, Roger. 2006. “Austrian Economics at the Cutting Edge.” Review of Austrian Economics 19: 231-41.

Lachmann, Ludwig M. 1956. Capital and Its Structure. London: G. Bell \& Sons.

— 1977. Capital, Expectations, and the Market Process. Kansas City: Sheed Andrews and McMeel.

Lindahl, Erik. 1939. Studies in the Theory of Money and Capital. London: George Allen \& Unwin.

Lundberg, Erik. 1937. Studies in the Theory of Economic Expansion. London: P. S. King \& Son.

Machlup, Fritz. 1958. "Equilibrium and Disequilibrium: Misplaced Concreteness and Disguised Politics.” In Machlup, Essays in Economic Semantics. $2^{\text {nd }}$ ed. New Brunswick, N.J.: Transaction, 1991. Pp. 43-72

MacKenzie, Douglas W. 2008. “The Equilibrium Analysis of Mises, Hayek, and Lachmann.” Working Paper, Department of Economics, SUNY-Plattsburgh.

Marget, Arthur W. 1938-42. The Theory of Prices: An Examination of the Central Problem of Monetary Theory. 2 Vols. New York: Augustus M. Kelley, 1966.

Mayer, Hans. 1932. “The Cognitive Value of Functional Theories of Price.” In Classics of Austrian Economics: A Sampling in the History of a Tradition. Ed. Israel M. Kirzner. London: William Pickering, 1994. Pp. 55-168.

Mathews, John A. 2006. "Ricardian Rents or Knightian Profits? More on Austrian Insights on Strategic Organization.” Strategic Organization 4: 97-108. 
Menger, Carl. 1871. Principles of Economics. Trans. James Dingwall and Bert Hoselitz. Auburn, Ala.: Ludwig von Mises Institute, 2006.

Menger, Carl. 1883. Investigations into the Method of the Social Sciences with Special Reference to Economics. New York: New York University Press, 1981.

—. 1892. “On the Origin of Money.” Economic Journal 2: 239-55.

Mises, Ludwig von. 1912. The Theory of Money and Credit. Indianapolis: LibertyClassics, 1981.

—. 1933. Epistemological Problems of Economics. Auburn, Ala.: Ludwig von Mises Institute, 2003.

— 1949. Human Action: A Treatise on Economics. Scholar's Edition. Auburn, Ala.: Ludwig von Mises Institute, 1998.

_. 1951. "Profit and Loss." In Mises, Planning for Freedom. South-Holland, Ill.: Libertarian Press, 1952. Pp. 108-50.

—. 1962. The Ultimate Foundation of Economic Science: An Essay on Method. Princeton, N.J.: Van Nostrand.

Morgenstern, Oskar. 1935. "Perfect Foresight and Economic Equilibrium.” In Selected Economic Writings of Oskar Morgenstern. Ed. Andrew Schotter. New York: New York University Press. Pp. 169-83.

Oakley, Allen. 1999. The Revival of Modern Austrian Economics: A Critical Assessment of Its Subjectivist Origins. Aldershot, U.K.: Edward Elgar.

O’Driscoll, Gerald P. 1977. Economics as a Coordination Problem: The Contributions of Friedrich A. Hayek. Kansas City: Sheed Andrews and McMeel.

O’Driscoll, Gerald P., and Mario J. Rizzo. 1985. The Economics of Time and Ignorance. Oxford: Blackwell.

Roberts, Peter W., and K. M. Eisenhardt. 2003. "Austrian Insights on Strategic Organization: From Market Insights to Implications for Firms.” Strategic Organization 1: 345-52.

Rothbard, Murray N. 1962. Man, Economy, and State: A Treatise on Economic Principles. Scholars Edition. Auburn, Ala.: Ludwig von Mises Institute, 2004.

— . 1991. "The End of Socialism and the Calculation Debate Revisited." Review of Austrian Economics 5(2): 51-76.

—. 1995. "The Present State of Austrian Economics” (1995). In Rothbard, The Logic of Action One: Method, Money, and the Austrian School. Cheltenham, U.K.: Edward Elgar, 1997. 
Salerno, Joseph T. 1991. "Commentary: The Concept of Coordination in Austrian Macroeconomics.” In Austrian Economics. Ed. Richard Ebeling. Hillsdale, Mich.: Hillsdale College Press. Pp. 325-43.

—. 1993. "Mises and Hayek Dehomogenized.” Review of Austrian Economics 6(2): 113-46.

— 1994a. “Ludwig von Mises’s Monetary Theory in the Light of Modern Monetary Thought.” Review of Austrian Economics 8(1): 71-115.

—. 1994b. "Reply to Leland B. Yeager.” Review of Austrian Economics 7(2): 111-25.

—. 1996. “A Final Word: Calculation, Knowledge, and Appraisement.” Review of Austrian Economics 9(1): 141-42.

—. 1999a. "Carl Menger: The Founder of the Austrian School.” In Fifteen Great Austrian Economists. Ed. Randall G. Holcombe. Auburn, Ala.: Ludwig von Mises Institute, 1999. Pp. 71100.

—. 1999b. “The Place of Mises's Human Action in the Development of Modern Economic Thought.” Quarterly Journal of Austrian Economics 2(1): 35-65.

—. 2002. "The Rebirth of Austrian Economics_-In Light of Austrian Economics.” Quarterly Journal of Austrian Economics 5(4): 111-28.

—. 2006. “Mises’s Favorite Anglo-American Economists.” Mises.org Daily Article. October 18.

Samuelson, Paul A. 1947. Foundations of Economic Analysis. Cambridge, Mass.: Harvard University Press.

Schelling, Thomas C. 1978. Micromotives and Macrobehavior. New York: Norton:

Selgin, George A. 1988. "Praxeology and Understanding: An Analysis of the Controversy in Austrian Economics.” Review of Austrian Economics 2: 19-58.

Stalebrink, Odd J. 2004. “The Hayek and Mises Controversy: Bridging Differences.” Quarterly Journal of Austrian Economics 7(1): 27-38.

Stromberg, Joseph A. 2004. "Introduction to Man, Economy, and State with Power and Market." In Rothbard, 1962. Pp. xix-lxxxviii.

Thornton, Mark. 1999. Review of Vaughn, Austrian Economics in America. Reviewed in Public Choice 98: 467-69.

Vaughn, Karen I. 1994. Austrian Economics in America: The Migration of a Tradition. Cambridge: Cambridge University Press

Walker, D. A. 1969. “Marshall's Theory of Competitive Exchange.” Canadian Journal of Economics 2(4): 590-98. 
Wicksteed, Philip H. 1910. The Common Sense of Political Economy. London: George Routledge \& Sons, 1933.

Williamson, Oliver E. 2000. “The New Institutional Economics: Taking Stock, Looking Ahead.” Journal of Economic Literature 38(3): 595-613.

White, Lawrence H. 1981. “Introduction to the New York University Press Edition.” In Menger 1883. Pp. vii-Xviii.

Wieser, Friedrich. 1914. Social Economics. London: Allen and Unwin, 1927.

Yeager, Leland B. 1994. "Mises and Hayek on Calculation and Knowledge.” Review of Austrian Economics 7(2): 93-109.

— 1995. "Rejoinder: Salerno on Calculation, Knowledge, and Appraisement.” Review of Austrian Economics 9(1): 137-39.

—. "Calculation and Knowledge: Let's Write Finis.” Review of Austrian Economics 10(1): 133-36.

Yu, Tony Fu-Lai. 2003. “A Subjectivist Approach to Strategic Management.” Managerial and Decision Economics 24(4): 335-45. 